Klinichna khirurhiia. 2018 May;85(5):10-13.

DOI: $10.26779 / 2522-1396.2018 .05 .10$

УДК 616.24-002.3-072.1-089.48-089.168

\title{
Ендоскопічні методи дренування хронічних абсцесів легенів та оцінка іх ефективності за допомогою сонографіi
}

\author{
В. В. Бойко ${ }^{1,2}$, А. А. Серенко ${ }^{1}$ А. Г. Краснояружський ${ }^{1}$, Д. В. Мінухін ${ }^{2}$, \\ В. Г. Грома ${ }^{2}$, Д. О. Євтушенко ${ }^{2}$
}

${ }^{1}$ Інститут загальної та невідкладної хірургії імені В. Т. Зайцева НАМН України, м. Харків,

${ }^{2}$ Харківський національний медичний університет

\section{Endoscopic methods of draining of chronic pulmonary abscesses and estimation of their efficacy, using sonography}

\author{
V. V. Boyko ${ }^{1,2}$, A. A. Serenko', A. G. Krasnoyaruzhskiy ${ }^{1}$, D. V. Minukhin ${ }^{2}$, \\ V. G. Hroma ${ }^{2}$, D. O. Yevtushenko ${ }^{2}$ \\ ${ }^{1}$ Zaytsev Institute of General and Urgent Surgery, Kharkiv, \\ ${ }^{2}$ Kharkiv National Medical University
}

Реферат

Мета. Оцінити за допомогою сонографії ефективність ендоскопічних методів дренування хронічних абсцесів легенів Матеріали і методи. На базі клініки Інституту проведено обстеження та лікування 98 хворих 3 хронічними абсцесами легенів. Хворих розподілили на дві групи: основну та порівняльну. Хворим основної групи разом із протизапальними препаратами системно та місцево призначали ліпосомальний препарат ліпін. У хворих порівняльної групи застосовували стандартні методи.

Результати. Ефективність ендоскопічного дренування порожнини хронічних абсцесів доведена позитивною ультразвуковою (У3) динамікою в більш ранні строки, ніж у разі застосування стандартних методів лікування. На підставі аналізу лабораторних показників встановлено суттєвий позитивний вплив застосованої методики на зниження рівня показників ендогенної інтоксикації.

Висновки. Результати свідчать про ефективність запропонованого методу ендоскопічного дренування порожнини хронічного абсцесу разом із комбінованою протизапальною терапією з використанням препарату ліпін та його перевагу перед стандартними схемами лікування.

Ключові слова: хронічний абсцес легені; ендоскопічне дренування; сонографічне спостереження.

Abstract

Objective. To estimate the efficacy of endoscopic methods of draining for chronic pulmonary abscesses, using sonography. Materials and methods. Examination and treatment of 98 patients, suffering chronic pulmonary abscesses, was conducted on the base of the Institute. The patients were divided into two groups: the main and the comparison one. Liposomal preparation of lipin was used locally together with systemic anti-inflammatory preparations in patients of the main group. The standard methods were applied in patients of the comparison group.

Results. Efficacy of endoscopic draining of the chronic abscesses cavity was proved by positive ultrasonographic dynamics in earlier terms, than while application of standard methods of treatment. Essential positive impact of the procedure applied towards lowering of the indices level of endogenous intoxication was established, basing on analysis of laboratory indices.

Conclusion. The results obtained witness efficacy of the proposed method of chronic abscess endoscopic draining together with combined anti-inflammatory therapy, using the lipin preparation, and its advantage over standard schemes of treatment.

Keywords: chronic pulmonary abscess; endoscopic drainage; sonographic observation.

Незважаючи на впровадження в клінічну практику нових методів лікування, адекватне дренування хронічних абсцесів легенів було і залишається однією із основних умов для клінічного одужання хворого або для оптимальної передопераційної підготовки [1 - 3]. Ендоскопічні способи дренування $є$ найбільш фізіологічними і найменш інвазивними $[4,5]$. Переваги ендоскопічного дренування полягають не тільки в можливості виконання процедури під місцевою анестезією зі збереженням кашльового рефлексу, а й у можливості подальших санацій порожнини деструкції з введенням у неї різних медикаментозних засобів $[6,7]$. Для здійснення процедури дренування лікар повинен мати повну інформацію про локалізацію, розміри, структуру патологічного вогнища, стан навколишніх тканин. У цьому сенсі рекомендуємо раціонально широке використання УЗ методу поряд з стандартними рентгенологічними [8 - 10].

Мета дослідження: оцінити за допомогою сонографії ефективність ендоскопічних методів дренування хронічних абсцесів легенів.

\section{Матеріали і методи дослідження}

На базі клініки Інституту проведено обстеження та лікування 98 хворих з хронічними абсцесами легенів. 
Хворих розподілили на дві групи: основну і порівняльну Порівняльну групу склали 48 хворих, яким, крім консервативного лікування, що включало протизапальну, антибактеріальну і дезінтоксикаційну терапію, застосовували стандартні підходи до ендобронхіальної санації вогнища гнійно-запального процесу. Основну групу склали 50 хворих, яким виконували ендоскопічне дренування абсцесу за власною методикою під візуальним контролем з використанням рентгеноконтрастних катетерів з подальшою санацією порожнини деструкції. Цим хворим разом з протизапальними препаратами системно застосовували ліпосомальний препарат ліпін до 2 разів на добу внутрішньовенно крапельно у дозі 10 мг/кг маси тіла. Місцево (ендобронхіально та для санації порожнини абсцесу) призначали суміш протизапальних препаратів (гідрокортизон, гатифлоксацин) та ліпіну. У хворих порівняльної групи у лікуванні хронічного абсцесу легені значне місце відводили стандартним методам та заходам.

Методика приготування та введення інфузійного розчину npenapamy ліпін. Суспензію ліпіну (виробництво ЗАТ «Біолік») готували безпосередньо перед застосуванням шляхом додавання до флакона, який містив 0,5 г ліофілізованого порошку, 10 мл стерильного 0,9\% розчину натрію хлориду. Приготований у такий спосіб препарат струшували до створення однорідної суспензії білого кольору. Після цього отриману суспензію розводили у 200 мл стерильного 0,9\% розчину натрію хлориду. Розчин ліпіну вводили хворим внутрішньовенно крапельно зі швидкістю 2 - 3 мл за 1 хв або 40 - 60 крапель за 1 хв. Препарат використовували згідно з інструкцією виробника не більше 2 разів на добу.

методика приготування суміші для місиевої санаціи трахеобронхіального дерева та порожнин абсцесів легенів. Суспензію ліпіну готували додаванням до флакона, який містив 0,5 г ліофілізованого порошку, 10 мл стерильного 0,9\% розчину натрію хлориду. Приготований у такий спосіб препарат струшували до створення однорідної суспензії білого кольору. Після цього отриману суспензію розводили у 100 мл стерильного 0,9\% розчину натрію хлориду. До суспензії ліпіну додавали 200 мг (100 мл) гатифлоксацину та 1 мл 2,5\% емульсії гідрокортизону. Суміш для санації струшували до створення однорідного розчину. Приготовану суміш вводили у порожнини деструкції та у трахеобронхіальне дерево. Суміш готували безпосередньо перед санацією.

Для аналізу лабораторної ефективності лікування вивчали показники ендогенної інтоксикації та перекисного окислення ліпідів (ПОЛ). Одними із найважливіших лабораторних показників цих процесів є рівні молекул середньої маси (МСМ), малонового діальдегіду (МДА), дієнових кон'югатів (ДК), супероксиддисмутази (СОД). Також вивчали показник лейкоцитарного індексу інтоксикаціі (ЛІІ). Для порівняльного аналізу використовували критерій Ст'юдента. 3 метою виявлення статистично достовірних даних у пацієнтів основної та порівняльної груп використовували початкові (на момент госпіталізаціі) та проміжні (на 10-ту добу лікування) значення вказаних параметрів.

Бронхоскопічні дослідження проводили під місцевою анестезією апаратом фірми Olympus BF TYPE 1T 180. Після евакуації гнійних виділень та визначення дренуючого бронха під рентгенологічним контролем виконували катетеризацію його устя або порожнини хронічного абсцесу поліхлорвініловим катетером.

У кожній групі виділили по дві підгрупи з аспіраційними і постпневмонічними абсцесами відповідно до патогенезу захворювання. Контроль ефективності дренування здійснювали за допомогою УЗ методу. УЗ критеріями ефективності лікування вважали зменшення розмірів порожнини (позитивна УЗ динаміка) та появу ознак ії облітерації. Після ендоскопічного дренування порожнина 3 щільною суспензією і дрібними гіперехогенними включеннями повітря значно зменшувалася і ставала більш повітряною. Під час контрольного ультразвукового дослідження (УЗД) виявляли облітерацію порожнини абсцесу.

Для УЗД органів грудної порожнини використовували аппарат фірми Toshiba Aplio 400 без попередньої підготовки хворого до дослідження з частотою 1 раз у 3 дні. Застосовували три типи датчиків (конвексний, секторномеханічний та лінійний) з частотами від 2,5 до 5,0 МГц.

\section{Результати}

За результатами інструментальних методів дослідження визначили частоту ураження різних анатомічних відділів легенів та біометричні показники порожнини деструкції (табл. 1, 2).Частоту ураження легеневої тканини правої та лівої легенів спочатку вираховували від загальної кількості хворих - 98. Найчастіше виявляли ураження правої легені, що особливо характерно для аспіраційних абсцесів, та поодинокі порожнини. Постпневмонічні абсцеси локалізувались у верхній або нижній частці легені, рідше - в середній, у гравізалежних сегментах S2, S3 і S6.

Аспіраційні абсцеси частіше локалізувались у нижній частці, у гравізалежних сегментах S2 i S6.

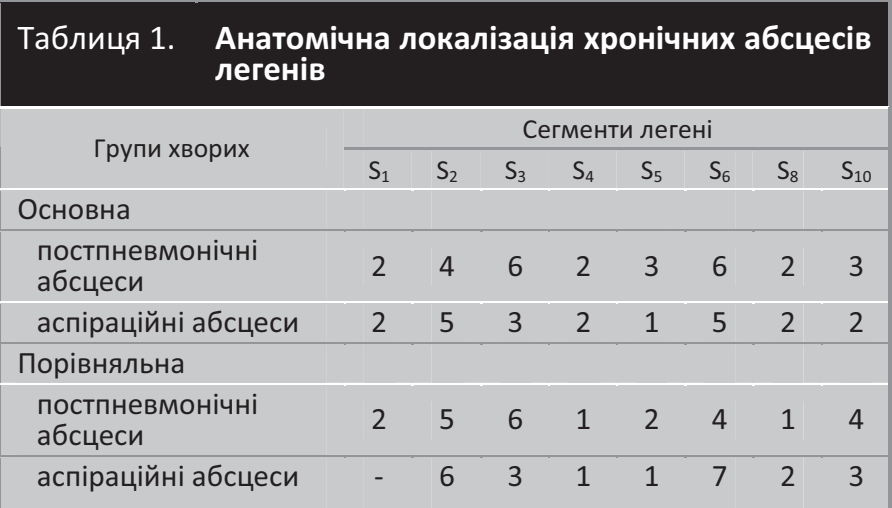

\begin{tabular}{|c|cccc|}
\hline Таблиця 2. & \multicolumn{2}{l}{$\begin{array}{l}\text { Біометричні показники хронічних абсцесів } \\
\text { легенів }\end{array}$} \\
\hline $\begin{array}{c}\text { Діаметр } \\
\text { порожнини } \\
\text { абсцесу, см }\end{array}$ & \multicolumn{2}{c|}{ Абсцес } & \multicolumn{2}{c|}{ Всього } \\
\hline $2-4$ & 21 & 19 & 40 & 40,8 \\
\hline $4-6$ & 16 & 12 & 28 & 28,6 \\
\hline $6-8$ & 9 & 8 & 17 & 17,3 \\
\hline $8-10$ & 7 & 6 & 13 & 13,3 \\
\hline
\end{tabular}




\section{Таблиця 3. Оцінка ефективності ендоскопічного дренування за даними УзД ( $\overline{\mathbf{x}} \pm \mathrm{m})$}

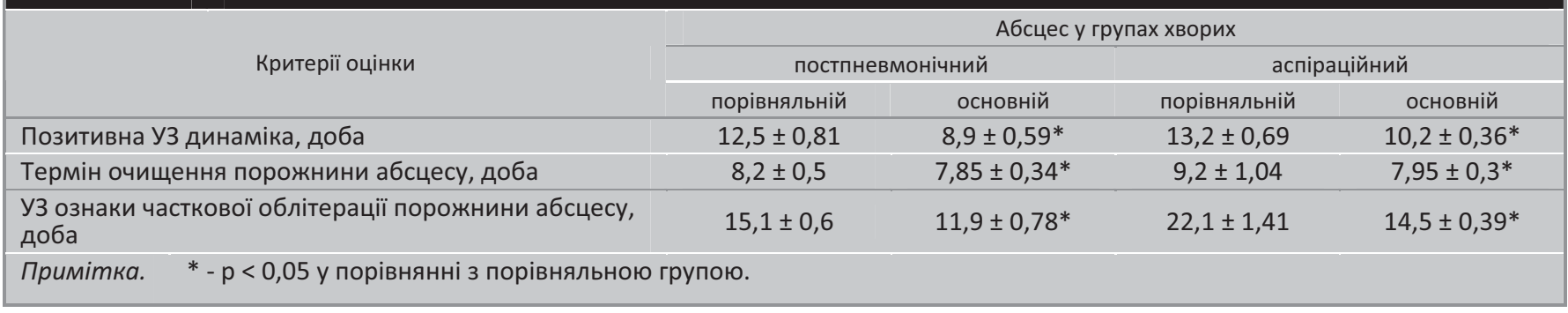

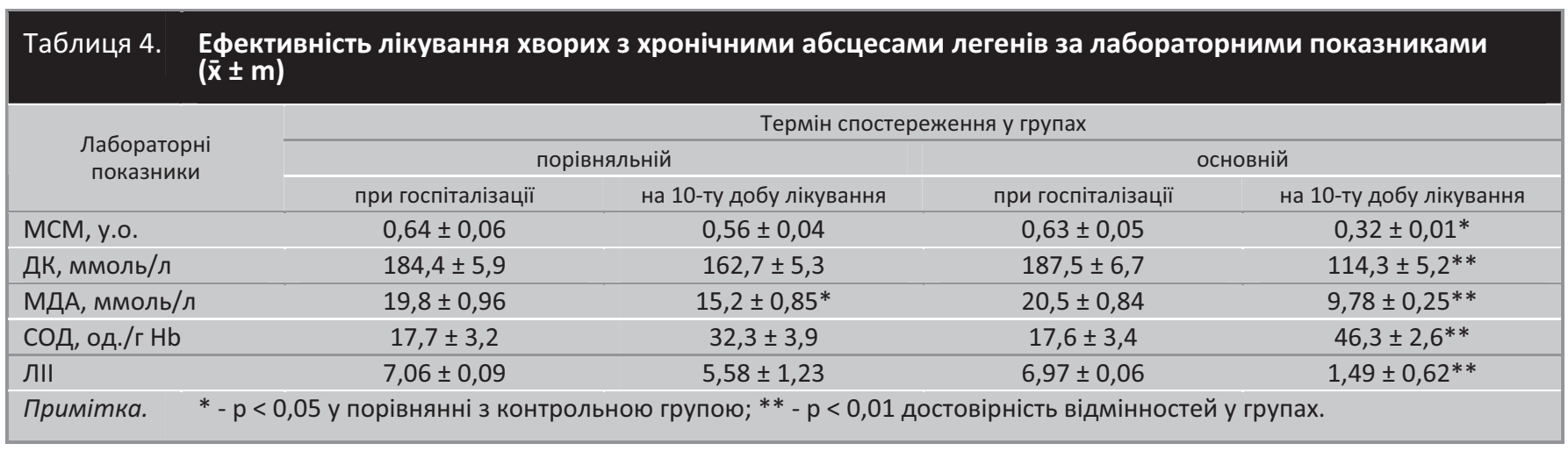

У хворих обох груп здійснювали динамічний контроль ефективності лікування. Ефективність ендоскопічного дренування порожнини хронічних абсцесів оцінювали за такими УЗ критеріями: зменшення розмірів порожнини абсцесу; поява відкладень фібрину на ії стінках - ознаки часткової облітерації порожнини; терміни очищен-

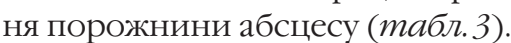

За аналізом лабораторних показників у хворих з хронічними абсцесами легенів, яким застосовували запропоновану суміш протизапальних препаратів - гідрокортизону, гатифлоксацину та ліпосомального препарату ліпін, чітко відстежували суттевий вплив застосованої методики на зниження рівня показників ендогенної інтоксикації та продуктів ПОЛ (табл.4).

\section{Обговорення}

Ендоскопічне дренування, застосоване у хворих основної групи з постпневмонічними абсцесами, було більш ефективне: очищення порожнини абсцесу відбувалось раніше на 2,3 доби ( $<$ 0,05), позитивну УЗ динаміку спостерігали раніше на 2,9 доби ( $<$ 0,05). Терміни часткової облітерації порожнини абсцесу відрізнялися незначно у порівнянні з контрольною групою. У хворих з аспіраційними абсцесами ці зміни мали більш виражений характер: позитивна УЗ динаміка з'явилася на 3 доби раніше ( $<$ < 0,05), ніж у порівняльній групі; часткова облітерація порожнини відбувалася в середньому на 1,2 доби раніше ( $<$ 0,05), очищення порожнини від гнійного вмісту - на 6,8 доби раніше $(\mathrm{p}<0,05)$.

В основній групі хворих відмічено достовірне зниження рівня МСM - $3(0,63 \pm 0,05)$ до $(0,32 \pm 0,01)$ у. о., тоді як у хворих порівняльної групи рівень МСМ знизився з $(0,64 \pm 0,06)$ до $(0,56 \pm 0,04)$ у.о. та був у 1,75 ра- зу більше ( $<$ 0,05). Порівняння рівнів показників ПОЛ показало, що рівень ДК у хворих основної групи знизився $3(187,5 \pm 6,7)$ до $(114,3 \pm 5,2)$ ммоль/л та був у 1,4 разу менше ( $<0,05)$, ніж у хворих порівняльної групи, у яких рівень ДК знизився 3 (184,4 \pm 5,9) до (162,7 \pm $5,3)$ ммоль/л. Рівень МДА знизився у хворих основної групи з $(20,5 \pm 0,84)$ до $(9,78 \pm 0,25)$ ммоль/л та був у 1,6 разу менше ( $<$ 0,05), ніж у хворих порівняльної групи, у яких рівень МДА знизився 3 (19,8 \pm 0,96) до (15,2 $\pm 0,85)$ ммоль/л. Оцінюванням активності антиоксидантної системи з'ясовано, що рівень СОД у хворих основної групи підвищився $3(17,6 \pm 3,4)$ до $(46,3 \pm 2,6)$ од./г Нb, а у хворих порівняльної групи - $3(17,7 \pm 3,2)$ до $(32,3 \pm 3,9)$ од./г Нb, що у 1,4 разу менше ( $<$ < 0,05). На 10-ту добу лікування ЛІІ, який обчислювали за формулою Кальф-Каліфа, у хворих основної групи становив $1,49 \pm 0,62$, що у 3,7 разу менше ( $<<0,05)$, ніж у хворих порівняльної групи $-5,58 \pm 1,23$.

\section{Висновки}

1. Отримані дані демонструють вірогідно більш високу ефективність запропонованого методу ендоскопічного дренування порожнини хронічного абсцесу у порівнянні з комбінованою протизапальною терапією з використанням препарату ліпін та його перевагу перед стандартними схемами лікування, що супроводжувалося більш швидким статистично достовірним регресом патологічного процесу та суттевим зниженням рівня ендогенної інтоксикації. Тобто дренування хронічного вогнища деструкції насамперед сприяє швидкому зменшенню розмірів порожнини і скороченню термінів іiі очищення.

2. Стандартне рентгенологічне обстеження при хронічних абсцесах легенів необхідно більш широко до- 
повнювати УЗД для визначення локалізації і розмірів порожнини абсцесу, вивчення його структури і динамічного спостереження під час лікувального процесу без зайвого променевого навантаження.

\section{References}

1. Balmasova IP, Blashentseva SA. Endoskopicheskie i immunologicheskie paralleli pri soputstvuyuschih kataralnom i gnoynom bronhitah u bolnyih ostryimi gnoynyimi abstsessami legkih. Grudnaya i serdechnososudistaya hirurgiya. 2001;(5):50-4. [In Russian].

2. Pavlov YuV. Ispolzovanie ultrazvuka dlya diagnostiki i lecheniya hirurgicheskih zabolevaniy legkih i plevryi. Hirurgiya. 2002;(4):82-6. [In Russian].

3. Sekela MV. Praktychna torakal'na khirurhiya. L'viv : Lohos; 2003. 315 s. [In Ukrainian].

4. Bisenkov LN, Salamatov AV. Dlitelnaya transbronhialnaya kateterizatsiya polostey destruktsii v lechenii ostryih abstsessov legkih s narushennoy bronhialnoy prohodimostyu. Vestnik hirurgii. 1998;157(5):112-5. [In Russian].

5. Reheda MS, Vanivs'kyy MM. Infektsiyni destruktsiyi lehen'. L'viv: Spolom; 2005. 92 s. [In Ukrainian].

6. Yarema IV, Chernehovskaya NE, Andreev VG, i dr. Bronhoskopiya v kompleksnom obsledovanii i lechenii bolnyih s abstsessami legkih. Vestnik hirurgii im. I. I. Grekova. 2000;(1):81-4. [In Russian].

7. Toma TP, Kon OM, Oldfield W. Reduction of persistent air leak with endoscopic valve implants. Thorax. 2007;(62):830-3. doi:10.1136/ thx.2005.044537.

8. Boyko VV, Florikyan AK, Avdosev YuV, i dr. Gnoynyie zabolevaniya legkih i plevryi; pod red. V.V. Boyko i A.K. Florikyana. Kharkiv: Prapor; 2007. 576s. [In Russian].

9. Shahov BE, Sazonov DV. Transtorakalnoe ultrazvukovoe issledovanie legkih i plevryi. N.Novgorod : Dempiks; 2002. 118 s. [In Russian].

10. Fataar S. Radiologically controlled drainage of pleural and pulmonary collections. Australas. Radiol. 2000;(2):111-6. doi: 10.1111/j.14401673.1990.tb02824.x 